\title{
The Origin of Indonesian Cattle and Conservation Genetics of the Bali Cattle Breed
}

\author{
K Mohamad, M Olsson, G Andersson, B Purwantara, H T A van Tol, \\ Heriberto Rodriguez-Martinez, B Colenbrander and J A Lenstra
}

\section{Linköping University Post Print}

N.B.: When citing this work, cite the original article.

This is the authors' version of the following article:

K Mohamad, M Olsson, G Andersson, B Purwantara, H T A van Tol, Heriberto RodriguezMartinez, B Colenbrander and J A Lenstra, The Origin of Indonesian Cattle and Conservation Genetics of the Bali Cattle Breed, 2012, Reproduction in domestic animals (1990), (47), SI, 18-20.

which has been published in final form at:

http://dx.doi.org/10.1111/j.1439-0531.2011.01960.x

Copyright: Blackwell Publishing http://www.blackwellpublishing.com/

Postprint available at: Linköping University Electronic Press http://urn.kb.se/resolve?urn=urn:nbn:se:liu:diva-74148 


\title{
The origin of Indonesian cattle and conservation genetics of the Bali cattle breed
}

\author{
Mohamad $\mathrm{K}^{1,3}$, Olsson $\mathrm{M}^{2}$, Andersson $\mathrm{G}^{2}$, Purwantara B ${ }^{1}$, \\ van Tol HTA ${ }^{3}$, Rodriguez-Martinez $\mathrm{H}^{4}$, Colenbrander $\mathrm{B}^{3}$, Lenstra $\mathrm{JA}^{3}$ \\ ${ }^{1}$ Faculty of Veterinary Medicine, Bogor Agricultural University, Bogor, Indonesia; ${ }^{2}$ Dept of \\ Animal Breeding and Genetics, Swedish University of Agricultural Sciences, Uppsala, \\ Sweden; ${ }^{3}$ Faculty of Veterinary Medicine, Utrecht University, Utrecht, The Netherlands; ${ }^{4}$ \\ Dept of Clinical \& Experimental Medicine, University of Linköping, Linköping, Sweden.
}

Running title: Conservation genetics of Bali cattle.

\section{Contents}

Both Bos indicus (zebu) and Bos javanicus (banteng) contribute to the Indonesian indigenous livestock, which is supposedly of a mixed species origin, not by direct breeding but by secondary cross breeding. Here, the analysis of mitochondrial, Y-chromosomal and microsatellite DNA showed banteng introgression of 10-16\% in Indonesian zebu breeds with East-Javanese Madura and Galekan cattle having higher levels of autosomal banteng introgression (20-30\%) and combine a zebu paternal lineage with a predominant (Madura) or even complete (Galekan) maternal banteng origin. Two Madura bulls carried taurine Ychromosomal haplotypes, presumably of French Limousin origin. There was no evidence for zebu introgression in five populations of the Bali cattle, a domestic form of the banteng.

Key words: DNA analyses, bos indicus, bos javanicus, indigenous cattle, Indonesia.

\section{Introduction}

As for wild species, one of the most severe threats to domesticated breeds is inbreeding and loss of genetic variation. In an effort to breed sustainable populations of domesticated animals the degree of genetic variation within breeds needs to be defined in order to develop productive breeding programs. Breeding of domestic cattle in developing countries such as Indonesia is critical for a sustainable agriculture and local production of high quality meat. Therefore, we have made an effort to define the genetic architecture of Indonesian domestic catttle breeds. The identification of genetic factors that influence the productivity and sustainability of Bali cattle is the long-term major focus of this research endeavour. In the short term genetic variation is often correlated with fitness and in a longer perspective, reduced variability may limit the possibility of a population to respond to a changing environment, such as diseases or parasites (Frankel \& Soulé 1981). In addition, the purity and the special characteristics of one domesticated breed could be endangered by hybridization with other related breeds. Prior to conservation and management it is crucial to recognize the degree of genetic variation in the population of interest. In a recently published study we aimed to uncover the origin of the Indonesian Bali cattle breed, as well as the level of genetic variation, inbreeding and the genetic purity in order to know which sub-population is more suitable to preserve (Mohamad et al 2009). Here we review these results and discuss their relevance from a conservation genetics perspective. 
Most domestic cattle breeds belong to either of the two species Bos Taurus or Bos indicus (zebu), which are both descendants from the wild aurochs (Bos primigenius). In contrast, the Indonesian Bali cattle breed is supposed to derive mainly from a third species, the wild banteng (Bos javanicus) as well as with introgression from zebu. Bali cattle is well-adapted to the sub-tropical climate in South East Asia and a perfect livestock for the local conditions. The banteng, the major species from which Bali cattle was domesticated is an extant but highly threatened species. Several factors including habitat loss and poaching are decreasing the current banteng population which is now found at very low numbers only on Java and Bali. However, the origin of Bali cattle has been uncertain and breeding records for Bali cattle does not support this dual origin from both banteng and zebu. Moreover, only sporadic molecular data existed prior to this study (Kikkawa et al 1995, Kikkawa et al 1981, Namikava 1981, Nijman et al 2003, Verkaar et al 2003), emphasizing the need for a rigorous assessment of the origin of this Indonesian cattle breed.

Bali cattle are kept on Bali, East Java and on isolated regions of Sumatera and Sulawesi and is very well adapted to small-scale village farming by being more petite than other breeds, has a high fertility, being resistant to many diseases and having a remarkable ability to grow and produce milk on low quality fodder (McCool 1992). Bali cattle has primarily been used for meat production in small scale units and is considered to be among the most important livestock in these highly populated regions of Indonesia. It is thus of crucial importance to maintain efficient breeding of healthy and productive Bali cattle. Domestication of Bali cattle is considered to have occurred in South-East Asia during 5,000-10,000 years before present. Unlike, breeds derived from Bos taurus, Bali cattle has since domestication not been subjected to such strong selection as the European domestic cattle breeds. Increased knowledge of the genetics of both Bali cattle and banteng is thus of importance also for understanding domestication processes.

\section{Material and Methods}

In order to study the Bali cattle population in Indonesia, we collected DNA from animals at five different locations (Bali, Sulawesi and three different locations at Sumatera). Included in the study were also other cattle breeds; Aceh, Pesisir and Filial Ongole, all sampled at five locations (three at Sumatera and two at West Java) and banteng individuals from a captive population. The maternal and paternal origin was studied by PCR-RLFP sequencing of a mitochondrial cytochrome $b$ gene segment and a Y-chromosomal SRY gene segment. In addition, the autosomal composition of the different population of breeds was investigated by genotyping 16 microsatellite loci recommended by FAO for studies of genetic variation and compared the data with genotypes for the same markers from seven Indian zebu populations (Kumar 2003). We estimated the genetic variation with the microsatellite data by counting the number of polymorphic loci, number of private alleles and calculated the observed and expected heterozygosities by using the Excel-based microsatellite toolkit. Nei standard genetic distances were estimated using the program Microsat and NeighborNet graphs were constructed by the program Splitstree. Model-based clustering was carried out using the program Structure, assuming admixture and correlated allele frequencies. Reproducible clustering was obtained after 30,000 burnin steps and 40,000 simulations. Clusters were either inferred or predefined as Indian zebu and Bali cattle, respectively and the program Distruct displayed results. 


\section{Results and discussion}

The predominance of zebu mitochondria in the Indonesian zebu breeds shows that not only zebu bulls but also zebu cows were imported. This is in contrast to the zebu populations in Africa and America, which emerged by systematic crossing of imported zebu bulls with taurine cattle (Bradley et al 1996, Loftus et al 1994). Banteng mitochondria in Indonesian Ongole populations as well as the autosomal microsatellite analysis indicate crossbreeding of zebu and local cattle with a banteng maternal origin.

The maternal origin of Bali cattle from five different locations on three isles is almost exclusively banteng with zebu origin found for only 1 out of 125 sampled animals. This is in contrast to the mixed maternal origin of Bali cattle from Malaysia (Nijman et al 2003), but agrees with the results obtained for a feral population of Bali cattle (Bradshaw et al 2006). When looking at the paternal origin, all Bali cattle in our study, with only one exception in South Sumatera, descend from banteng bulls. The observed heterozygosity is clearly lower than the expected values in Bali cattle, presumably because of light inbreeding within local populations (data not shown). Extremely low levels of variability was detected in the banteng individuals which probably reflects them being sampled from a isolated captive population (data not shown). The different Bali cattle populations appear to have almost identical levels of genetic variation with no introgression of other breeds and will probably not risk outbreeding if translocated. Even though the banteng population was less informative than we hoped, when adding genetic distances it links them nicely to one branch with the population to Bali cattle with a distance that probably corresponds to their inbreeding (not shown). Our data indicate that Bali cattle on different locations in Indonesia has been kept separate from zebu, this in contrast to mixed zebu-banteng Bali cattle populations from Malaysia (Nijman et al 2003). Evidently, the history and breeding of Indonesian cattle has resulted in a unique genetic resource that combines the general tolerance of zebu to tropical and dry climates with the adaptation of domestic banteng to Indonesian conditions and husbandry.

In this research project we have taken advantage of the availability of a unique population of Bali cattle and other Indonesian cattle breeds. Obtained results may be used to develop improved breeding programs. Our future studies of the genomes of these cattle breeds will allow identification of crucial genetic factors important for sustainable breeding of domestic cattle in Indonesia.

\section{Acknowledgements}

This work has been carried out as part of the Asia Link Project "Reproductive biotechnology: modern technology to improve livestock production under traditional Asian conditions" supported by the European Union (ASI/B7-301/98/679-035). Additional support was obtained from the Swedish Research Council (VR), Stockholm, Sweden.

FAO: (http://lprdad.fao.org/cgi-bin/getblob.cgi?sid = -1,50006220)

Programs used for data analysis:

Microsatellite toolkit: (http://animalgenomics.ucd.ie/sdepark/ms-toolkit/)

Microsat: (http://hpgl.stanford.edu/projects/microsat/)

Spliztree: (http://www.splitstree.org/)

Structure: (http://pritch.bsd.uchicago.edu/software.html)

Distruct: (http://rosenberglab.bioinformatics.med.umich.edu/distruct.html) 


\section{Corresponding author's address}

Göran Andersson, Section of Molecular Animal Genetics and Bioinformatics, Department of Animal Breeding and Genetics, Swedish University of Agricultural Sciences (SLU), Uppsala, Sweden

P.O. Box 597, S-75124 Uppsala, Sweden (Tel: +46-18-4714973, Fax: +46-18-4714673, email: goran.andersson@slu.se, http://www.slu.se/)

\section{Conflicts of interest}

Nothing to declare.

\section{References}

Bradley DG, MacHugh DE, Cunningham P, Loftus RT, 1996: Mitochondrial diversity and the origins of African and European cattle. Proc Natl Acad Sci USA 93 5131-5135.

Bradshaw CJA, Isagi Y, Kaneko S, Bowman DMJS, Brook BW, 2006: Conservation value of non native banteng in northern Australia. Conserv Biol 20 1306-1311.

Frankel OH, Soulé ME, 1981: Conservation and Evolution. Cambridge University Press, Cambridge.

Kikkawa Y, Amano T, Suzuki H, 1995: Analysis of genetic diversity of domestic cattle in East and Southeast Asia in terms of variations in restriction sites and sequences of mitochondrial DNA. Biochem Genet 33 51-60.

Kikkawa Y, Takada T, Sutopo, Nomura K, Namikawa T, Yonekawa H, Amano T, 2003: Phylogenies using mtDNA and SRY provide evidence for male-mediated introgession in Asian domestic cattle. Anim Genet 34 96-101.

Kumar P, Freeman AR, Loftus RT, Gaillard C, Fuller DQ, Bradley DG, 2003: Admixture analysis of South Asian cattle. Hered 91 43-50.

Loftus RT, MacHugh DE, Ngere OL, Balain DS, Badi AM, Bradley DG, Cunningham EP, 1994: Mitochondrial genetic variation in European, African and Indian cattle populations. Anim Genet 25 265-271.

McCool C, 1992: Buffalo and Bali cattle-exploiting their reproductive behaviour and physiology. Trop Anim Health Prod 24 165-172.

Mohamad K, Olsson M, Van Tol HTA, Mikko S, Vlamings BH, Andersson G, RodriguezMartinez H, Purwantara B, Paling RW, Colenbrander B, Lenstra JA, 2009: On the origin of Indonesian cattle. PloS ONE 4 e5490.

Namikawa T, 1981: Geographic distribution of bovine Hemoglobin-beta (Hbb) alleles and the phylogenetic analysis of the cattle in Eastern Asia. Z Tierzuchtg Zuchtgsbiol 98 151-159. 
Nijman IJ, Otsen M, Verkaar ELC, De Ruijter C, Hanekamp E, Ochieng JW, Shamshad SBM, Rege JEO, Hanotte O, Barwegen MW, Susilawati T, Lenstra JA, 2003: Hybridization of banteng (Bos javanicus) and zebu (Bos indicus) revealed by mitochondrial DNA, satellite DNA, AFLP and microsatellites. Hered 90 10-16.

Verkaar ELC, Vervaecke H, Roden C, Romero-Mendoza L, Barwegen MW, Susilawati T, Romero Mendoza L, Nijman IJ, Lenstra JA, 2003: Paternally inherited markers in bovine hybrid populations. Hered 9 565-569. 


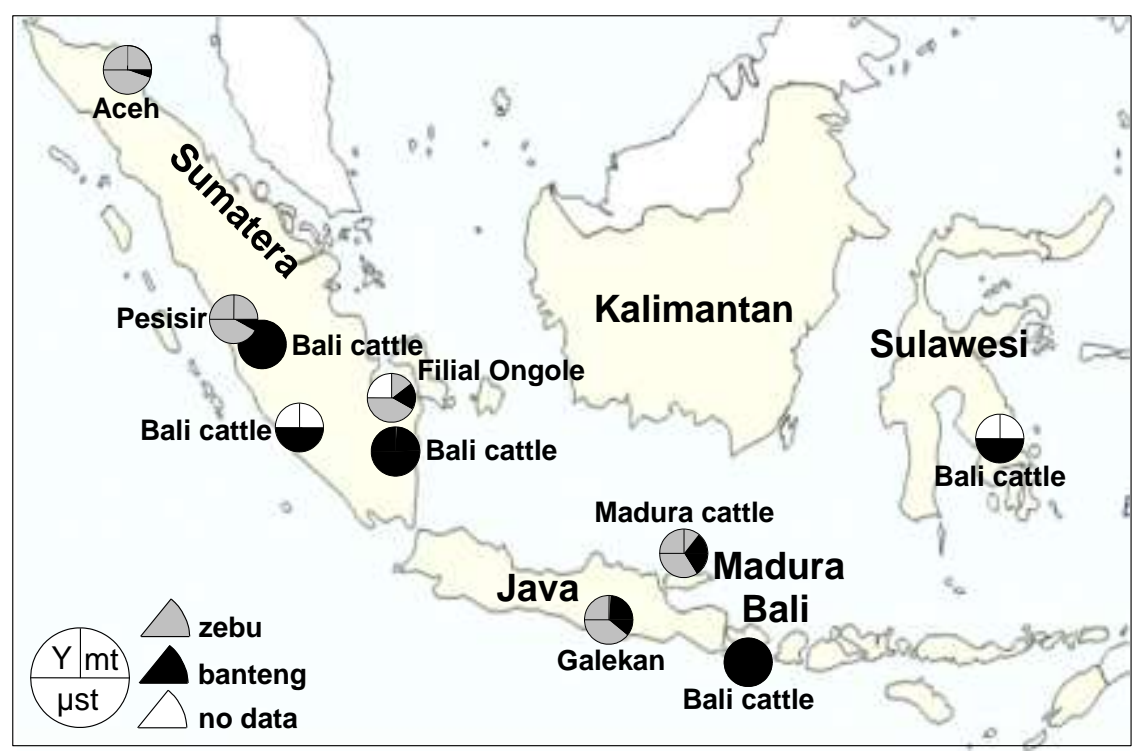

Figure 1. Locations of sampling and genetic constitution of Indonesian cattle populations. The species origin of the paternally transmitted Y-chromosomes (Y), maternally transmitted mitochondrial DNA (mt) and autosomal microsatellite alleles $(\mu \mathrm{st})$ is represented by black and gray shading of the indicated circle segments. Figure adapted from Mohamad et al 2009.

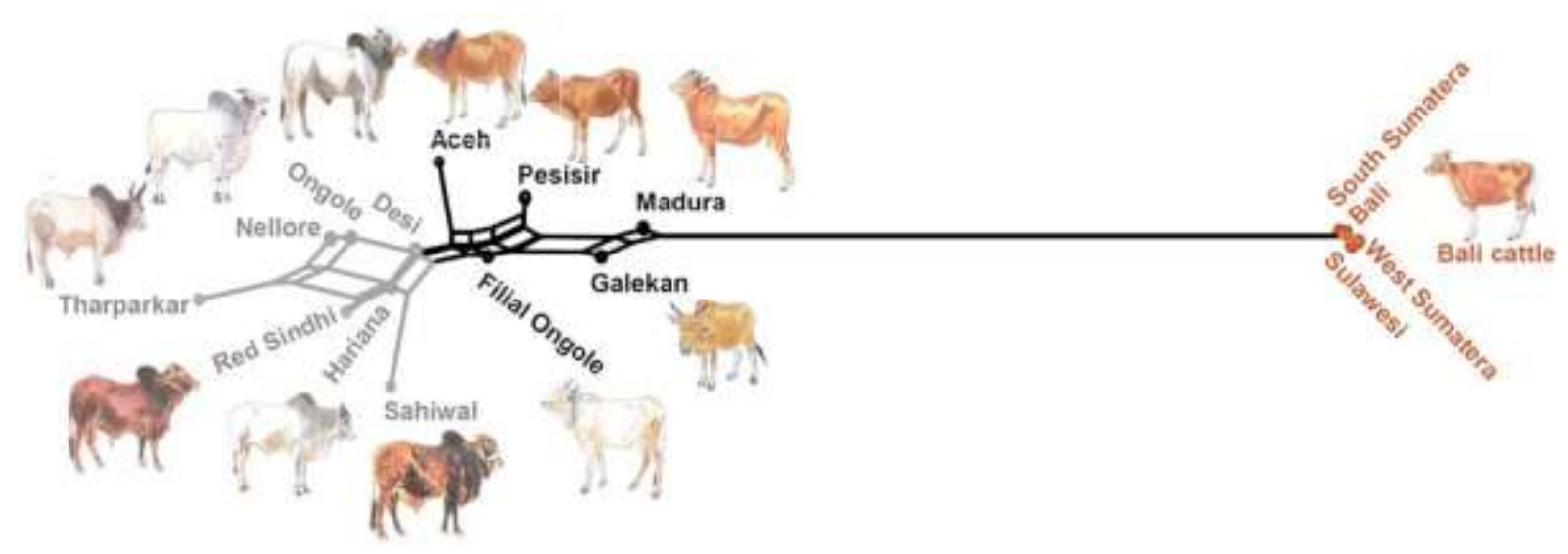

Figure 2. NeighborNet graph of genetic distances of Indonesian cattle populations. The animal pictures are from (Felius 1995) or were drawn from photographs. Figure adapted from Mohamad et al 2009. 